\title{
EQUALIZING THE BANK POSITION AND BUSINESSES IN CREDIT AGREEMENT WITH THE GUARANTEE OF MORTGAGE
}

\author{
Moch Najib Imanullah \\ Faculty of Law, Universitas Sebelas Maret \\ E-mail: imanullahnajib@yahoo.com
}

\begin{abstract}
The Security Law, which regulates the land mortgage has significance meaning to move real sector, thus it can support the development of national economy. In this case, the traders, on the one hand, need capital for business activities, while on the other side of the capital owners seek to profit from their investment. Bank as an intermediary is required to be careful. An implementation of the precautionary principle is to have collateral for loans to businesses. One of the collateral is immovable asset (land), which is secured by the Mortgage. In practice, stipulation of mortgage is still more in favor of the bank. If this is allowed, it can be conditions that would adversely affect the parties. Thus, we need to make updates Security Law that balances position of banks and businesses, which in accordance with the attitude of mutual cooperation with based on the fundamental values which are reflected in the philosophical basis of the Indonesian nation.
\end{abstract}

Keywords: Security law, Mortgage, Equalizing principles

\section{A. INTRODUCTION}

The study on guarantee shall begins by elucidating The Civil Code Article 1131 "all movable and immovable properties of the debtor, either present or future, serve as securities for the personal obligations of the debtor. Article 1132 state that "the properties serve as joint guarantees for his creditors; the proceeds thereof is to be divided among the creditor in proportion to their loan, unless there exists a legal order of priority among the creditors." Article 1131 and 1132 Civil Code regulate the properties which being able to be guaranteed and treatment if the obligation not able to be paid and the rights to each creditors. Furthermore, people are discontented with the regulation generally, furthermore asking properties as a guarantee, which the debtor was not being able to fulfilled the appointment, then his creditor could be sured to perform his rights by achieve the higher position than the other creditors (Subekti,1996:78). The guarantee institution in Indonesia had a slow progress. In other words, there is not a renewal of law or the new regulation regarding guarantee institution which already known since the Civil Code is exist. Nevertheless, there is no any regulation according to institution that already there in society and also already acknowledged by

Yustisia Vol. 7 No. 1 January - April 2018

Equalizing The Bank Position... 
jurisprudence, for example fiduciary intermediary institution ( Sri Sudewi Masjchoen Sofwan, 1980:3). The security law contains many weaknesses, both in terms of the instruments and the implementation. Security Law is not on the whole system, in other words remains sporadic and inconsistent (Mariam Darus Badrulzaman, 1198:1). By that, a few side trying to take the roles in Security Law development, for instance by ELIPS Project which initiative by Coordinator Minister for the Economy collaborating with USAIN doing assessments in security of law that generate security law structure, guarantee treaty, aspects of credit guarantee, and mortgage (Noormin S. Pakpahan, 1998:i).

In practice, there are several kind of guarantee as goods guarantee, such as : mortgage, fiduciary, pledge and warehouse receipt. Otherwise, there is private guarantee. In considering that the guarantee issue is really important on economic events, especially in real sector, therefore the governments strieve to renewal the regulations about guarantee, in order to achieve the modern security law that able to contribute the certainity of regulation and development of economic sector.

As the progress of national development in economy sector, there will be a big funding needed and a guarantee rights institution which able to serve legal certainty for any related parties, and also to stimulate society contribution in development to reach prosperous, and righteous community according to Pancasila and 1945 Constitution of The Republic of Indonesia. Since the Law Number 5 of 1960 on Agrarian Principal Fundamental Regulation ( Agrarian Law), the provision about mortgage as guarantee rights institution which able to be charged upon land or not related to the land, is not formed yet. The provision of the hypotheek as regulated in Book II Indonesian Civil Code about land, and the provision about credietverband in staatsblad 1908-542 which already formed by Staatsblad 1937-190, according to Article 57 Law Number 5 of 1960 on Agrarian Law, still applied until the mortgage regulation is made, it might not appropriate with the credits activities, regarding to the progress of Indonesian economy. As the improvement in the rules and rights administration about land, and also in order to fulfill the community needs, besides property rights, right to cultivate, right to build which appointed as an objects of mortgage by Agrarian Law, right to use on land shall be registered, it is also necessary to be charged by mortgage. By those things, it is necessary to form a Regulation that regulate on mortgage along side with the goods that regulate the land, as explained in Agrarian Law, at the same time to manifest unification National Land Regulation. According to the consideration, therefore the Law Number 4 of 1996 on Mortgage of Land and Goods Related to Land ( Morgage Law) had been promulgated (Article 30). Nevertheless, studies on mortgage must be continued. Some thoughts have been delivered to reach modern security law, particularly governing 
mortgage that pointing the nuance of efficient in security law and eliminating inharmonious of security law in Indonesia (Moch. Isnaeni, 2014 :13-15).

\section{B. PROBLEM STATEMENT}

Based on the introduction, this article analyze on equalizing the bank position and businesses in credit agreement with the guarantee of mortgage. studies on mortgage must be continued. Some thoughts have been delivered to reach modern security law, particularly governing mortgage that pointing the nuance of efficient in security law and eliminating inharmonious of security law in Indonesia

\section{RESEARCH METHODS}

The research is a normative law research to analyze the principle of law (Soerjono Soekanto dan Sri Mamudji, 2007:101), in order to increase the security law which equalizing the position between the creditor and debtor, by using secondary data (Soerjono Soekanto dan Sri Mamudji, 2007:12) sourced from primary data that is the mortgage law and any related regulation, and secondary data from reviews on law aspect of mortgage that have been published in scientific journals resulting from research and literatures. Data has been obtained by doing literature review through contents identification. Data validity has been done by source critical. Further, data analysis conducted by doing legal interpretation grammatically. Editing analysis style used as to analysis technique (Crabstree,1995).

\section{DISCUSSION AND RESEARCH RESULT}

The research is a normative law research to analyze the principle of law (Soerjono Soekanto dan Sri Mamudji, 2007:101), in order to increase the security law which equalizing the position between the creditor and debtor, by using secondary data (Soerjono Soekanto dan Sri Mamudji, 2007:12) sourced from primary data that is the mortgage law and any related regulation, and secondary data from reviews on law aspect of mortgage that have been published in scientific journals resulting from research and literatures. Data has been obtained by doing literature review through contents identification. Data validity has been done by source critical. Further, data analysis conducted by doing legal interpretation grammatically. Editing analysis style used as to analysis technique (Crabstree,1995). 


\section{Philosophy and Politics of Mortgage}

Economic development, as a part of national development, is one of the attempts to create the welfare of community according to Pancasila and 1945 Constitution of the Republic of Indonesia. In order to maintain the development, both sides of government and communities as an individual and legal institution, the huge fund is required. As the development events increase, so do the needs of the fund, which mostly can be found from credit issues. Considering the importance of credits issues In development process, it is duly to give protection to the recipients and contributor that able to give legal certainty for any related parties (general explanation point 1 of The Mortgage Law).

In Article 51 Agrarian Law, the guarantee institution had already been provided which can be charged to right of the land, that is mortgage, as the replacement of hypotheek and credietverband. In 30 years since the Agrarian Fundamental Law, the mortgage institution was not being able to do its function well, due to lack of law that regulated comprehensively, as stipulated by Article 51. Since that time, based on the regulation in Article 57, the Hypotheek, the Book II Indonesian Civil Code is still applied and the provision Credietverband in Staatsblad 1908-542 as have been changed with Staatsblad 1937-190, as long as concern to the provisions which have not any regulation based Agrarian Law. The provisions in the regulation derived from era of Netherlands and based on the land law that applied before the national law, as the provisions written on Agrarian Fundamental Law and intended to be temporal while waiting to the establishment of law as stipulate by Article 51 above. Therefore, the provisions is not appropriate with the National Land Law and in the reality its not being able to accommodate the progress in credits issues as the effect from the increasing of economy development. As a result the differences between perspectives about the issues in land mortgage implementation, for an example, the inclusion of executorial title, the implementation of execution and so on, therefore the regulation being underestimated in giving legal certainty in relating to credits issue (general explanation point 2 The Mortgage Law).

Based on the fact, the regulation about guarantee of land institution needs to be assigned with the specification :

a. Provide precedence positions or formerly to its owner

b. Always adhering to the objects that guaranteed wherever its objects exists 
c. Fulfill special principle and publicity so therefore will be able to bind the third party and provide the certain of law

d. Accessible and the execution is certain (general explanation point 3 The Mortgage Law).

\section{Scope and Definition of Mortgage Regulation.}

Mortgage is a right of guarantee on land for the repayment of certain debts, which provide precedence position to the creditor towards another creditor. In this case, if the debtor contravening the assessment, the creditor who has mortgage is able to sell through the auction which order to be guarantee according to the regulation, with rights precede than the other creditor. The precedence position is surely not reduce preference of state's accounts receivable according to the existing regulation.

In Agrarian Fundamental Law, those that appointed as rights of land which being able to be debt guarantee with burdened by Mortgage are Property rights, cultivation rights title, the building rights title, as the rights of land that shall registered and able to transferable. Thus, in Article 51 Agrarian Law things that should be regulated by law are mortgage of title, cultivation rights title, the building rights title. Rights to Use Title is not mentioned in Agrarian Law as mortgage, because rights to use title is not included in rights on the land which shall registered and its rights did not qualify to be the guarantee of debts. In its developments, rights to use has to be registered, namely rights to use title that given to state's land. Part of the rights to use title, according to its characteristic able to transferable which are given to the individual and civil law institution.

In Law Number 16 of 1985 on Flats, Rights to Use Title that mentioned above can be used as guarantee with fiduciary. In Mortgage Law, Rights to Use Title determined as Mortgage's object. Therefore, mortgage is the only institution of guarantee on land, and then the unification of National Land Law is done as one of the Agrarian Law purposes. The statements about Rights to Use Title can be used as a Mortgage object is an adaption from Agrarian Law with the developments of Rights to Use Title itself and also the needs of community. In addition to realize the unification of the National Land Law, and no less important, is that the appointment of right to use as a mortgage object, for them who holds the title, the majority made up of economically weak groups are not capable to have land with Rights Title or Building Rights Title, be opened chances for obtaining credit as they needed, to use the land as guarantee.

Right of use on state lands, which although obliged to be registered, but due to its non-transferable, such as the right to use by the name of the government, the 
right to use by the name of religious bodies and social affairs, and the right to use by the name of representatives of foreign countries, which the entry into force period is unspecified duration and given for land used for certain purposes, is not a mortgage object. Similarly, over the right to use the land can not be burdened mortgage, because it does not meet the requirements above. However, considering the development needs of society and development in the future, in Agrarian Law, there is possibility to be also appointed as the mortgage objects, if it has met the requirements as mentioned above. It will further be regulated by Government Regulation. Thus, the rights over the land designated as a mortgage object by Law are rights title, cultivation rights title, building rights title and right to use State land which by their nature can be transferred. For the right to use of land, rights title opens the possibility to serve as debt guarantee burdened by mortgage in the future, if the requirements have been met. Land of Rights Title that has been communal ownership, and lands that are used for purposes of worship and other sacred purposes, though listed, because according to the nature and purpose is not transferable, cannot be burdened by mortgage.

The mortgage that regulated in Agrarian Law, basically, is mortgage burdened to rights of land. However, often in reality it can be found such as building, plants, masterpiece, which remains one unified with the land as guarantee. National land law based on the Adat (custom) Law. which uses the principle of horizontally separation. According to that, in the relation with the building, plants, masterpiece, the Agrarian Law applies the principle of horizontally separation. Concerning the principle of horizontally separation, the goods that unified with the land based on the regulation is not the part of the land. By that, every legal action about the right of the land, not covering the objects by itself. Nevertheless the implementation of the principle of Adat Law is not absolute, instead always notices on the facts and the needs of community . Based on the Adat Law, according to the principle of horizontally separation, in Mortgage Law, that the imposition of land, is possible to cover the goods which mentioned above. The issues justified by the regulation, as long as the goods unified with the land and its participation become the guarantee, expressly stated by the parties in the granting of mortgage deed. Buildings, plants, and masterpiece that followed to be the guarantee is not limited to rights holder by concerned rights to land, but also includes another party. While the building using a basement, that physically nothing to do with the existing buildings on the surface of the earth, are not included in the regulation provisions on mortgage according to Mortgage Law.

Based on the regulation, the land deed official has a power to make deeds of transfer of land rights and other certificates in order charging land rights, which 
the deed set, as evidence of certain legal actions regarding the land located in the area of work respectively. In its capacity as mentioned above, the deed made by the land deed official is an authentic deed. Definition of legal acts imposition land title by the authority of the land deed official, include making of building rights title of rights titile land referred to Article 37 Agrarian Law and making of deed in order imposition mortgage stipulated in the Mortgage Law.

In providing mortgage, mortgage providers must be present before the land deed official. If for whatever reason can not present itself, the other party shall appoint as their proxies, with the procuration burdened mortgage, in the form of an authentic deed. Making this procuration to the notary, also assigned to the land deed official whose existence until the district area, in order to facilitate the provision of services to those in need. At the time of making the procuration and deed of granting mortgage, should have no conviction on notary or the land deed official concerned, that the person who give mortgage has the authority to take legal actions against the object mortgage charged, although no certainty about its authority. In the step of administering a mortgage by the grantor to creditors, Mortgage concerned unborn.

Land mortgage appears when its registered, codification into books at Agrarian Office. By that, the certainity of the land mortgage is really important for creditor. In that time, not only determining the priority position to any creditors, but also determining its position in their relation with any creditors and the owner of mortgage, with same land as guarantee. In achieving certainty at registration, In mortgage law stated that the date of concerned land book of mortgage is on seventh day after acceptance of letters that needs to the registration completely by the Agrarian Office, and if on the seventh day is holiday, then the books given in the next day. In order to reach the main position for the creditor, its also regulated that the deeds of mortgage giving and any related latter for registration, must be submitted by the land deed official to the Agrarian office at least seven days after the signatories. Nevertheless the implementation of the issues mentioned above has a time limit, that is one month for registered rights of land and three months for unregistered rights of land.

Due to the nature of mortgage that accessoir on certain account receivable, which supporting main agreement that is credit agreement (Herlin Budiono, 2011:65), thus the giving must be a follow-up of the main agreement, which is based on a debt-agreement or other agreement, then its birth and existence are determined by the credit that guaranteed repayment. Agreements that result to a relationship of debts can be made by deed under hand or by authentic deed, depending on the provisions of the law governing the agreement material (explanation of Article 10 section 1 Agrarian Law). In the case of related account 
receivables switch to other creditors, mortgage guarantee, because the law also switch to the creditor. Registration of mortgage transition does not require deed of the land deed official, but based on a deed of transfer of guaranteed claims.

The transition recording carried out on the land books and related mortgage certificate, as well as the land book and land rights certificates as guarantee. Likewise mortgage becomes void due to the law, if for any repayment or other causes, the account receivable are becomes removed. In this case also the recording of the abolition of the relevant Mortgage was based on a written statement from the creditor, that the concerned account receivables are removed In the concerned land book of mortgage appended a note of the abolishment of such rights, while the certificate abolished. Similar recording, called the write-off, or better known as the "roya", has applied to land book and land rights certificate which was originally used as guarantee. Certificate of land rights that has been spiked with the note, handed back to the right holder.

By not ignoring the legal certainity to the related parties, simplicity of the administration of mortgage, besides the transition issues and the elimination of account receivables is also appear to the elimination the rights because another reason, in this case is the elimination of creditor, removed objects of mortgage based on establishment of rating by The Head of District Court, and the removed guaranteed Rights of Land. In respect of the issues that mentioned above, Mortgage Law regulates procedures on how to record transition and eliminated Mortgage, including deletion or roya.

One of the strong specification of mortgage is easy and certain in its implementation, if the debtor violate the agreement. Although generally the provisions about execution has been regulated in Civil Law, it is necessary to include exclusively about the execution of Land Mortgage, which manage the parate executie institution. Otherwise, the certificate of Mortgage clarified as the replacement grosse deed hypotheek, which execute hypotheek on the land appointed as a requirement.

In order to abridging the implementation of Mortgage Regulation to the parties, to the Head of District Court is given the authority, which : the determination of giving an authority to the creditor to manage the objects of mortgage, the determination issues regarding to the request of cleaning mortgage object, deletion mortgage.

To guarantee the legal certainty as well as provide the protection to the parties, the Mortgage Law managed the administrative sanction or penalties for concerned executor, to violation or negligence in fulfillment of any each technical job. Otherwise, if it is meet with requirements, they still can be civil plaint/or criminal claims. 
Mortgage Law is an implementation of Agrarian Law which adjusted with the conditions and manage new issues relating to the institution of mortgage as elaborated above, with the scope: mortgage objects, giver and holder of mortgage, procedure to give, regist, transfer, and deletion of mortgage, execution of mortgage, deletion the mortgage, and administrative sanctions.

\section{Characteristics of mortgage}

Mortgage itself cannot be shared, unless there is agreement in the giving mortgage deed. If the mortgage is being burdened to several land rights, it can be agreed on the giving mortgage deed, that the payment of secured debt can be made by installments with equal to value individual land rights that are part of the mortgage object, which will be exempted from the mortgage, so then mortgage only burden the rest of the mortgage object to ensure the rest of the outstanding debts (Article 2 Mortgage Law). Mortgage burden the whole object. Half portion of secured debt have been redempted does not mean liberation half of object from mortgage burden, but the rights is still weighing on the whole object for the remaining outstanding debts (explanation of Article 2 section 1 Mortgage Law). The principle that the mortgage shall not be divided can be obliged if it is agreed expressly in mortgage law, for instance that mortgage charged to some rights over land consists of several parts, each of which is an entity that stands alone and can be assessed separately (explanation of Article 2 section (2) Mortgage Law).

Debt secured by mortgage may be a debt which is already existing, or has been agreed over a certain amount, or is in amount determined upon application for the execution of the mortgage under an indebtedness agreement or an agreement result to the indebtedness relationship. Mortgage can be established to secure a debt originating from a legal relationship, or for one or more debts originating from several legal relationships. For example, the debt arising from payments made by the creditor to the needs of the debtor in the framework of the implementation of the bank guarantee. Agreements that may cause the relationship of debts can be form of lending agreement and other agreements, such as the management agreement on the assets of people who are immature or who are under guardianship, which is followed by a mortgage (Article 3 section (1) Mortgage Law). Often happens where debtor owed to more than one creditor, secured by a mortgage with a deed granting of mortgage, charged on the same land. In such cases, the relationship among creditors are governed by their own, while in relation to the debtor, the giver points to one of the creditors who will act on their behalf (explanation of Article 3 section 2 Mortgage Law). 


\section{Object, Subject, Procedure, Execution, and Omission}

a. Object of mortgage

The land titles which may be imposed by mortgage shall be: 1) freehold title; 2) cultivation rights title; 3) building rights title, freehold title, cultivation rights title, and building rights title are rights of land as defined in the Agrarian Law (explanation of article 4 paragraph (1) Mortgage Law). Besides those rights that has been mentioned, right to use on State lands which under the applicable In addition to the rights to the land, right to use on State lands shall be registered and transferable by their nature and can also be charged by mortgage. Imposition of mortgage on right to use in a land of freehold will be regulated further by a government regulation (Article 4 paragraph (1), (2) and (3) Mortgage Law). Mortgage can also be imposed on the right of land with buildings, plants, and works that have been or will be there as unity to the land, and which belong to the holders of land and expressly stated in the deed granting mortgage. If the buildings, plants, and work are not owned by the holder of land, the imposition of mortgage over these objects can only be done with the signing on the giving mortgage deed concerned by its owner or person authorized to it by him with the authentic deed (Article 4 section 4 and 5 Mortgage Law).

Object of mortgage can be imposed with more than one mortgage to ensure repayment of the debt. If an object imposed with more than one Mortgage, the rank of mortgage is determined according to the date of its registration at the Land Office. Rank of mortgage that registered on the same date specified by creation date of the giving mortgage deed concerned (Article 5 Mortgage Law). If the debtor breached the promise, the holder of the first Mortgage has the right to sell the object of mortgage on its own power through a public auction, and take the repayment of the receivable from the sale of (Article 6). Mortgage still follow the object in the hands of whoever the object is held (Article 7).

\section{b. Giver and mortgage holders}

Mortgage provider is natural person or legal entity that has the authority to take legal actions against on object with mortgage. The authority to conduct legal action on the object with mortgage should be on mortgage provider upon registration of mortgage. Mortgage holder is an individual or legal entity that serves as the parties indebted (Articles 8 and 9).

c. Procedures for granting mortgage, transition, and the termination of mortgage

Granting mortgage preceded by a promise to provide a mortgage as repayment of certain debt, which is poured in and an integral part of the 
agreement concerned debts or any other agreement that raises debt. Giving mortgage done by making the deed by the land deed official in accordance with the legislation in force. If the object of mortgage form on land that converted from old rights but has fulfilled the requirements to be registered, but the registration process hasn't been made, granting mortgage in the same time with registration application. In the deed shall be disclosed: 1) the name and identity of the holder and the givers of mortgage; 2) the domicile of the parties, and if among them there are domiciled outside Indonesia, for him must also listed a domicile of place in Indonesia, and in the case of domicile that option is not listed, the office of land deed official where the deed created considered as chosen domicile; 3) the appointment is clearly a debt or debts guaranteed; 4) the value of mortgage; 5) a clear description of the object of mortgage (Article 11 section (1)).

In the deed can be included promises, such as: 1) the promise that limits the authority of the Mortgage to rent the object of mortgage and / or determine or change the term of the lease and/or receiving the rent in advance, except with the prior written approval of mortgage holders; 2) the promise that limits the authority of the mortgage giver to change the shape or the arrangement of Mortgage objects, except with the prior written approval of the holders of mortgage; 3 ) the promise which authorizes the holder to manage the objects of mortgage based on the Chairman of the Court whose jurisdiction covers the object of mortgage if the debtor breaches promise; 4) the Promise which authorizes the holder to save the object with mortgage, if it is necessary for the execution or to prevent the loss or canceled right because unfulfilled or breaching the law; 5) the promise that the holder of the first mortgage has the right to sell on its own power the object of mortgage if debtors default; 6) the promise given by the holder of the first mortgage that the object will not be cleared from the mortgage; 7) The promise that the giver of mortgage will not release their rights to the object without the prior written approval of the holders of mortgage; 8) The promise that the mortgage holders will get all or part of the compensation received for the repayment from the giver mortgage to pay the debt if the object loss its right by the giver of mortgage or for public interest; 9) The promise that the mortgage holders will get all or part of the insurance money received from the giver of mortgage for repayment of loans, if the object insured; 10) The promise that the giver will clear the object with mortgage at execution time (Article 11 section 2).

The promise which authorizes the holder to have an object if debtors default, null and void (Article 12). Granting Mortgage shall be registered at the Agrarian Office. No later than seven (7) working days after the deed signing, The land deed official shall send Deed Granting Mortgage and other necessary to the Agrarian Office. Mortgage registration performed by the Agrarian Office will 
result to land book of mortgage and record it in a land book of land rights as the object of mortgage and copy such records on certificates of land rights. Date of land book is the seventh day after the date of receipt of complete documents required for registration and if the seventh day falls on a holiday, land book given in the next working day. Mortgage comes on a date book land exist.

As proof of their mortgage, Agrarian Office publishes certificate in accordance with the existing regulation. As discussed earlier, that the certificate of mortgage load with the words "FOR JUSTICE UNDER THE ONE ALMIGHTY GOD". Certificate of mortgage has executorial power equal to a court decision which has obtained permanent legal force and effect as a substitute grosse acte hypotheek. Unless otherwise agreed, the certificate of land rights that have been stamped returned to holders of land rights. Certificate of mortgage submitted to shareholders mortgage holders.

Power of attorney imposing mortgage shall be made by notarial deed or by the land deed official and meet the following requirements: 1) Not contain power to perform legal acts other than the charge of mortgage; 2) Not contain power of substitution; c) Include explicitly object with mortgage, the amount of debt, and the name and identity of the creditor, the name and identity of the debtor if the debtor is not giving encumbrance (Article 15 section 1).

The power to impose mortgage irrevocable or can not be ended by any cause except for power that have been implemented or because it has expired (Article 15 section 2). Power of attorney imposing mortgage over land rights that has been registered shall be followed by the deed granting mortgage not later than one (1) month after given (Article 15 section 3). Power of attorney imposing mortgage over land rights that have not been registered shall be followed by the manufacture of deed granting mortgage no later than 3 (three) months after awarded. Such provisions are not applicable in terms power of attorney imposing mortgage given to certain credit guarantees set out in the legislation in force. Power of attorney imposing mortgage that's not followed by the manufacture of deed granting mortgage within the time specified, null and void.

If account receivables are secured by mortgage switch because cessie, subrogation, inheritance, or other causes, such mortgage switch because the new law to creditors (Article 16 section 1). Mortgage shift must be registered by the new creditors to the Agrarian Office. The registration of shifting mortgage is done by the Agrarian Office to write in land books and copy such records on certificate of land rights. The record date on the land book is the seventh day after the date of receipt of complete documents required for registration of transfer of mortgage and if the seventh day falls on a holiday, the date record by the next working day. Mortgage shift into force for third parties on the record date. 
The deed granting mortgage form and content, form and content of the land book, and other matters relating to the procedures for granting and registration for mortgage defined and organized by the Government Regulation referred to in Article 19 Agrarian Law. Mortgage void due to the following matters: 1) Termination of the debt that is guaranteed by the mortgage; b) Release of mortgage by mortgage holders; c) Cleaning mortgage based on the rank by the Chairman of the Court; d) Termination of rights on land that imposed mortgage (Article 18 Mortgage Law).

Abolishment of mortgage as it is released by the holder is done by giving a written statement regarding the release of the holder mortgage to the giver. Abolishment of mortgage because of clearing encumbrance based on the rank by the chairman of the court because the applicant who buy the land right is imposed by the mortgage so that the land right is clear from any charge of mortgage. Abolishment of mortgage because of clearing encumbrance not causing the clearing of debt that been guaranteed mortgage buyer, either in a public tender at the order of the Chairman of the Court or in a voluntary purchase, can request to the holder of the mortgage to clear any mortgage that exceeds the purchase price. Cleaning object of burden mortgage is done by a written statement from the holder of mortgage containing to clear any mortgage that exceeds the purchase price. If the mortgage object loaded more than one mortgage and there is no agreement between the holders of mortgage on cleaning objects with mortgage that exceeds the purchase price, the buyer then may apply to the Chairman of the Court whose jurisdiction covers the location of the object to establish the purge of morgage and also establishes provisions regarding the distribution of auction proceeds among the indebted and rank them according to the laws in force.

Request cleaning objects on mortgage can not be done by the buyer of the object, if such purchasing is done by buying and selling voluntary and in the deed granting mortgage concerned the parties have expressly pledge that the mortgage object will not be cleared from the burden mortgage.

\section{d. Mortgage Execution}

If the debtor default, then based on: 1) the rights holders of mortgage first to sell the objects, or 2) executorial title contained in mortgage certificates, object with mortgage sold through a public auction in accordance with the procedures specified in legislation for the settlement of accounts receivable of mortgage holders (Article 20 section 1 Mortgage Law).

Based on agreement of providers and holders of mortgage, mortgage sales can be executed under hand if so it will be obtained the highest price that benefits all parties. Sales execution can only be made after the expiration of one month 
since notified in writing by the provider and /or holders of mortgage to the parties concerned and published it at least in two newspapers circulating in the region concerned and / or local mass media, as well as no party raised objections. Every promise to carry out the execution contrary to these provisions, is null and void. Until recently issued an announcement for the auction, the sale can be avoided with the repayment of debt secured by the mortgage and its execution costs that have been incurred. If the giver of mortgage bankrupt, mortgage holders still authorized to exercise all rights acquired under the terms of Mortgage Law.

\section{e. Deletion of Encumbrance Right}

After the mortgage removed, Land Office shall delete the record of encumbrance right in the land book of land title and its certificate. With the void of mortgage, the concerned mortgage certificate shall be revoked, and together with the land book of mortgage, it shall be declared null and void by the Agrarian Office. If due to a particular reason the certificate is not returned to the Agrarian Office, this shall be recorded in the land book of mortgage. An application for deletion shall be filed by the party concerned by attaching the mortgage certificate already provided with a note by the creditor that the mortgage is void because the account receivables secured by mortgage have been fulfilled, or a written statement from the creditor that mortgage is void because the account receivables secured by mortgage have been fulfilled or the creditor released the mortgage.

In the event the creditor is not wiling to give a statement, the party concerned may file an application for deletion to the Head of District Court in the jurisdiction where the mortgage is registered. In the event the application for deletion arises from a dispute being examined by another District Court, the application shall be filed to the head of District Court examining the dispute. An application for deletion of mortgage pursuant to District Court decree shall be filed to the Head of the Agrarian Office together with the copy of the District Court decree. Agrarian Office shall delete the record of mortgage under the procedure stipulated in the prevailing laws and regulations within 7 (seven) working days upon receipt of the application. In the event a debt payment is fulfilled in installments the void of mortgage over the mortgage object shall be recorded in the land book and the mortgage certificate, and the land book and the certificate of land title which have been released from mortgage. (Article 22 Mortgage Law).

Observing mortgage in Mortgage Law, it seems that the bank as a creditor has a better position (Moch Isnaeni, 2014: 23). This is understandable, because the banks are required to conduct business in accordance with the precautionary principle (Sulistyandari, 2012: 227). The implementation of the precautionary 
principle is to require collateral in lending. In fact, for businesses that become customers of debtors, use of assets as collateral is in order to optimize the economic benefits for the development of its business assets. Thus needs to be done is the development of security law by developing a credit agreement based on the principle of balance, as mandated by the Consumer Protection Law. If this is hard to do, then the credit agreement must promote the principle of proportionate in the rights and obligations of the parties. Equally important that credit agreement since the parties have the intention to make an agreement, negotiated, signed a treaty, do the rights and obligation that been agreed upon, and terminate the agreement should be based on the principle of good faith, including good faith subjective is honesty that must exist during the pre-contract and good faith that is rational and worthy objective that must exist at the time of execution of the contract (Ridwan Khairandy, 2013: 92).

Mortgage synonymous with land rights. When the rights to the land as guarantee, then the viewpoint of the parties do not have to solely profit, but still puts the attitude in harmony, mutual cooperation, courtesy and preserving social ethics. The legal system of the Indonesian nation must continue to have a dignified identity in the arena of international life without disregarding other fundamental legal principles that have been universally recognized (Moch Isnaeni, 2015: 5-6), and pay attention to the fundamental values that are reflected in the basic philosophy of (way of life) of the Indonesian nation, like hetrogen race, religion, and culture, namely Pancasila which base on religious, humanity, and social, which is the source of all law (RA Retno Murni, 2015: 10), including when it will update Indonesia Security law in which governs the mortgage.

\section{E. CLOSING}

The existence of goods guarantee, like mortgage, is an implementation of the precautionary principle which is mandated by the Banking Act. Mandate of the Act is given as the banks are just intermediaries who bridge the flow of capital / investment of the investors and the public at large to the businesses and people that need capital. However, considering the existence of "kindly" capital for businesses are needed to run dynamically, then in applying the precautionary principle by imposing good guarantee is done selectively, in the sense applied to credit with risk. For credit with high prospective, business actors of the micro and small businesses, the existence of a guarantee is only as a supplement and not decisive in lending, even can be eliminated. Meanwhile, business operators need to be awaken that the loan repayment is a "life breath" to the sustainability of its business. Balancing the rights and obligations between banking and business actors, with a legal instrument in the form of legislation, including security 
arrangements with the Mortgage, will be very difficult even will not be achieved, but what can be done is the right and the obligation be proportionalized.

\section{BIBLIOGRAPHY}

Books:

Badrulzaman, Mariam Darus, 1998, Kerangka Hukum Jaminan Indonesia dalam Hukum Jaminan (Indonesia Legal Guarantees Framework), ELIPS Project: Jakarta.

Budiono, Herlin, 2011, Ajaran Umum Hukum Perjanjian dan Penerapannya di Bidang Kenotariatan (General Teaching on The Guarantee Law and Its Implementation in The Notary Field), Citra Aditya Bakti: Bandung.

Crabstree, Benjamin F, 1995, Doing Qualitative Research, Sage Publication: London:

Isnaeni, Moch, 2014, Peran Hukum Jaminan dalam Bisnis Perbankan: Procediing Konferensi nasional Hukum Perdata (Role of The Guarantee Law in The Banking Business: National Conference Proceding on The Private Law), Asosiasi Pengajar Hukum Keperdataan, November 2014.

Khairandy, Ridwan, 2013, Hukum Kontrak Indonesia dalam Perspektif Perbandingan (Indonesia Contract Law in The Perspective), FH UII Press: Yogyakarta.

Pakpahan, Noormin S., 1998, Hukum Jaminan Indonesia (Indonesia Guarantee Law), Jakarta: ELIPS Proyek. R.A. Retno Murni, 2015. "Prinsip Hukum Perikatan Adat dalam Sistem Hukum Perikatan Nasional". Makalah Plenary Session Konferensi Nasional Hukum Perdata II, Denpasar, 16-17 April 2015, APHK dan Fakultas Hukum Universitas Udayana.

2015. Prinsip Syariah dan Adat dalam Pembangunan Sistem Hukum Perikatan Nasional Indonesia. Makalah Plenary Session Konferensi Nasional Hukum Perdata II (Sharia Pronciple and Adat Law in The Development of Indonesia Engagement Law System. Plenary Session Paper in The National Conference of Private Law), Denpasar, 16-17 April 2015, APHK dan Fakultas Hukum Universitas Udayana.

Soekanto, Soerjono dan Sri Mamudji, 2007. Penelitian Hukum Normatif - Suatu Tinjauan Singkat (Nomative Legal Research- A Simple Review), RajaGrafindo Persada: Jakarta. 
Sofwan, Sri Sudewi Masjchoen, 1980, Hukum Jaminan Indonesia Pokok-pokok Hukum Jaminan dan Jaminan Perorangan (Indonesia Guarantee Law, Principles on The Guarantee Law and Personal Guarantee), BPHN: Jakarta.

Subekti, 1996, Pokok-pokok Hukum Perdata (Principles on The Private Law), Intermassa: Jakarta.

\section{Journals:}

Sulistyandari, 2012, "Lembaga dan Fungsi Pengawasan Perbankan Di Indonesia".

Mimbar Hukum, Volume 24 No. 2, June 2012 